\title{
A MAGYAR TÁRSADALOM AZ ELSŐ VILÁGHÁBORÚ ÉS TRIANON UTÁN
}

\section{HUNGARIAN SOCIETY IN THE AFTERMATH OF THE GREAT WAR}

\author{
Bódy Zsombor \\ egyetemi docens, Pázmány Péter Katolikus Egyetem Bölcsészet- és Társadalomtudományi Kar Szociológiai Intézet, Budapest \\ body.zsombor@btk.ppke.hu
}

\begin{abstract}
ÖSSZEFOGLALÁS
Trianon után a magyar társadalom több új jelenséggel ismerkedett meg, illetve korábban elindult változások felgyorsulását élhette át; ezek azonban - ellentétben a második világháború társadalmi hatásaival - nem vezettek a társadalomszerkezet radikális átalakulásához. Az újdonságok, illetve változások - Trianon minden egyedi hatása mellett is - nem egyedül a magyar társadalmat jellemezték, a legtöbb európai hadviselő országban hasonló átalakulások mentek végbe a háború következtében. Míg a háború és Trianon a demográfiai folyamatokra hosszabb távon kevéssé hatott - folytatódott a várható élettartam növekedése és a termékenység fokozatos csökkenése -, addig radikálisan új helyzetet teremtett a magyar gazdaság tágabb nemzetközi integrációja és további fejlődési lehetőségei tekintetében. Miközben a magyar társadalom egészében sikerrel alkalmazkodott az új gazdasági környezethez, voltak vesztes csoportok is, akik pozícióik relatív gyengülését élték meg. Ugyanakkor a háború számos változásnak adott lökést, mint például a női munkavállalás és egyenjogúság, s jó néhány olyan intézményi vagy technikai innovációt kényszerített ki, amelyek azután hosszabb távon is megmaradtak, például az adórendszerben vagy az állam gazdasági szerepvállalása terén, vagy éppen a lakáspiac átformálódásában. A háború után bekövetkező egyensúlyvesztés után aránylag hamar új stabilitás alakult ki a nagyobb társadalmi erők között, mindenekelőtt a vidéki és a városi társadalom csoportjai közötti kapcsolatok újra piaci alapra helyezésével, amit az állam piacot helyettesítő, elosztó tevékenységének leépítése tett lehetővé.
\end{abstract}

\section{ABSTRACT}

After the Trianon Peace Treaty, Hungarian society became acquainted with several new phenomena and experienced the acceleration of earlier changes; however, unlike the social effects of World War II, they did not lead to a radical change in the structure of society. Even with Trianon's tremendous influence, novelties and changes were not unique to Hungarian society, and most European countries underwent similar transformations as a result of the war. While the Great War and Trianon had little effect on demographic trends in the longer term - continued life expectancy growth and a gradual decline in fertility - they radically created a new context for the wider international integration of the Hungarian economy and further opportunities for development. While Hungarian society as a whole has been successful in adapting to the new economic environment, there have also been groups who have experienced a relative weakening of their positions. At the same time, the war has given impetus to many changes, such as 
women's employment and equality, and has forced a number of institutional or technical innovations that have been maintained over the longer term, such as in the tax system, or the role of the state as an economic factor, or in the transformation of the housing market. After the war, imbalances were relatively soon re-established between the major social forces, in particular by re-establishing relations between rural and urban groups on a market basis, made possible by the dismantling of the state's substitutionary distribution activities.

Kulcsszavak: első világháború, Trianon, a háború társadalmi következményei, gazdaság az 1920-as években

Keywords: World War I, Trianon, social consequences of the war, economy in the 1920s

1918 novemberében a katonák hirtelen hazatértek a frontokról, illetve kiváltak a hadsereg kötelékéből. Egyedül november 5. és 25. között 1,3 millió katona özönlött az országba (Révész, 2019, 59.). Ehhez járultak még az eleve is a hátországban állomásozó alakulatokból szétszéledő katonák. A hazatérés gyors demográfiai hatásai a következő év során világosan leolvashatóak a statisztikai adatsorokról. Az 1918-19. téli házasodási hullám csúcsa februárban volt, 25 728-cal, egy második csúcs májusban következett be 21560 -nal. 1919 és 1922 között minden más hónapban húszezer alatt maradt a házasságkötések száma, sőt többnyire a tízezret sem érte el (Magyar Statisztikai évkönyv, 1925, 25.). A háború hirtelen véget értének következményeként 1919 augusztusában 25 426, szeptemberben 26 632, októberben 27701 gyerek született a trianoni Magyarország területén. Még decemberben is 24 202-en születtek. Ezzel szemben júliusban még csak 15 166, a megelőző hónapokban pedig 13-14 ezres születésszámot mutattak a statisztikák (Magyar Statisztikai évkönyv, 1925, 27.). Az 1919. augusztus-októberi születésszámok az év első feléhez képest 80-90\%-os növekedést mutatnak. A háború vége és a katonák hazatérte tehát - 1918-19 telének minden bizonytalansága ellenére - lehetőséget teremtett sokak számára a családalapításra és a gyermekvállalásra. Ezek a megugró számok minden bizonnyal a háború alatt elhalasztott vagy elmaradt egyéni döntések bepótlását mutatják.

Ez egyértelmüen látszik abból is, ha éves bontásban vizsgáljuk a házasságkötéseket. Az összeomlást követő hullámokat megelőzte a világháború éveiben a házasságkötési kedv csökkenése. Amint az 1. ábra mutatja, a háborús években - nyilván a házasságkötésre leginkább hajlamos életkorú férfiak katonai szolgálata és a romló, bizonytalan gazdasági helyzet miatt - csökkent az ezer lakosra jutó házasságkötések száma, a frontok felbomlása és a harcok lezárulta után viszont, minden bizonytalanság ellenére, nagyon sok nő és férfi kötött házasságot. Ez az egyének szintjén az elmaradt házasságkötések pótlását jelentette. Az emelkedő 
irányzatú kilengést követően azonban a házasságkötések aránya visszaállt arra a magasságra, ahol a háború előtt is volt.

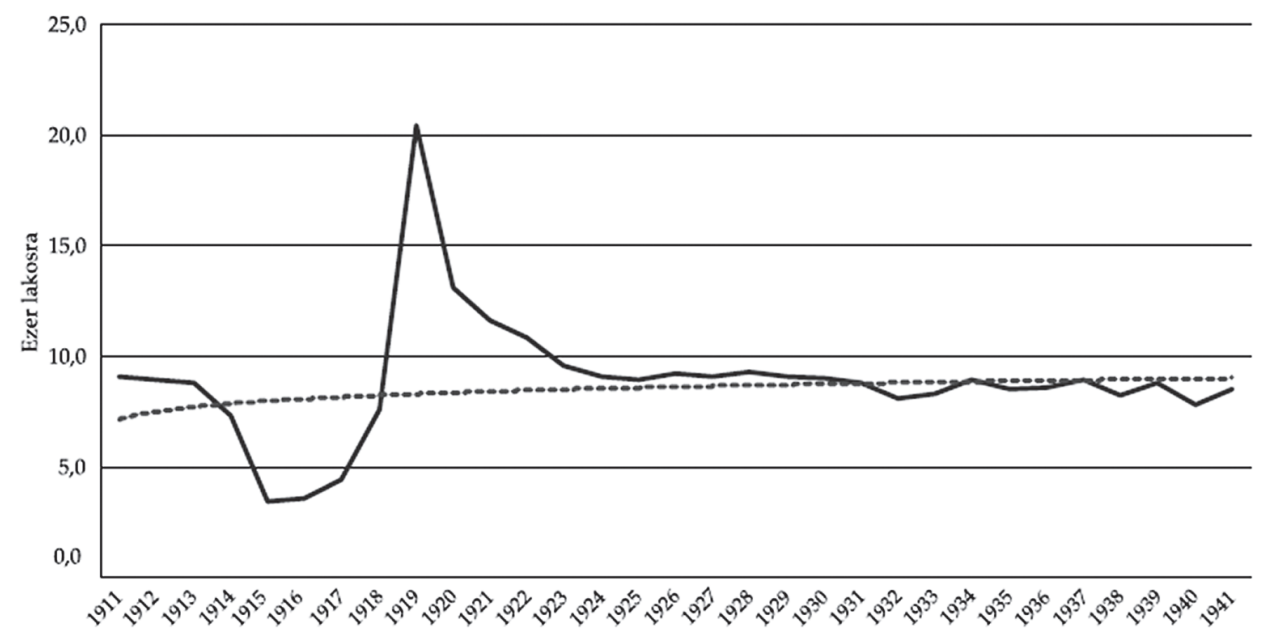

1. ábra. A házasságkötések arányának alakulása Magyarországon 1911 és 1941 között (Koloh, 2018, 15.)

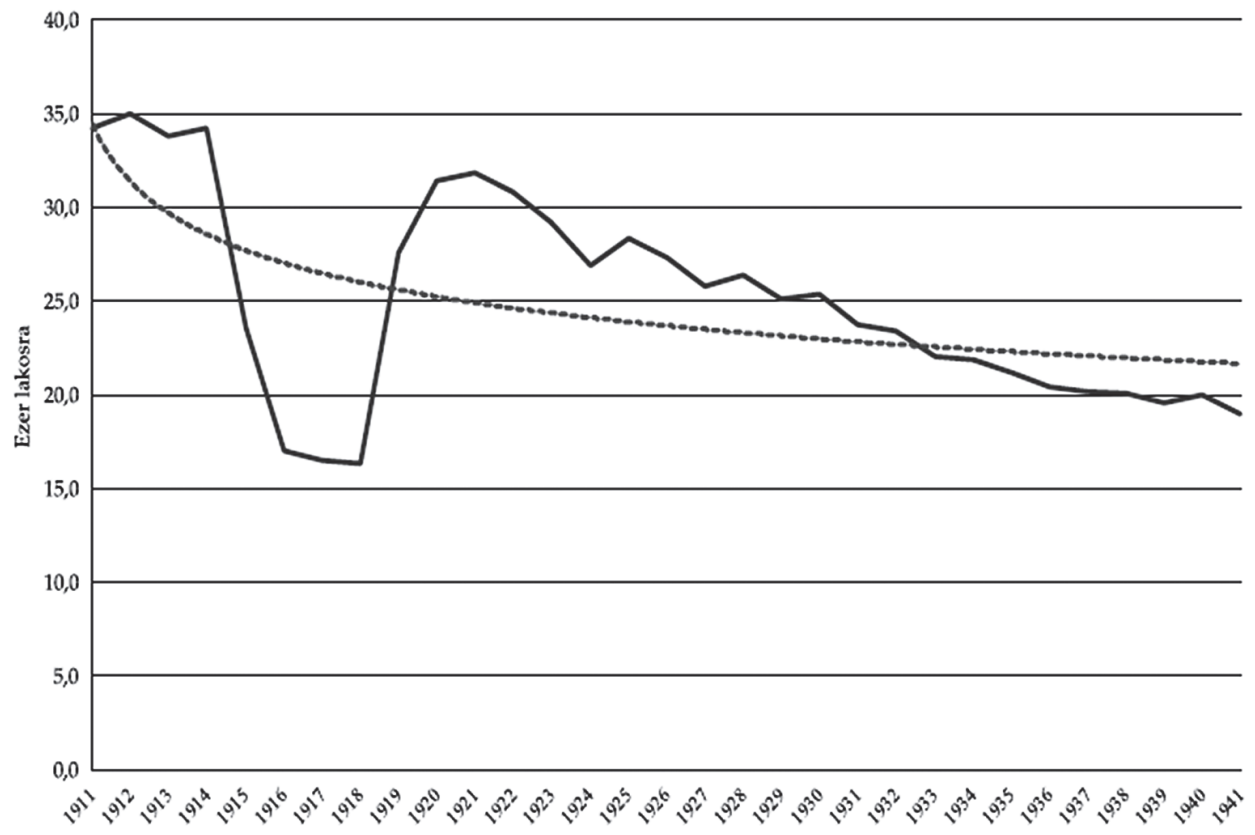

2. ábra. Az élve születések ezer lakosra eső arányának változása a trianoni Magyarország területén, 1910-1941 (Koloh, 2018, 24.) 
Természetesen a demográfiai magatartásnak ezek a rövid távú kilengései nem határozták meg azokat a hosszabb távú trendeket, amelyek a 19. század végétöl jellemzőek voltak a magyar népesedési folyamatokra. Az élve születések ezer lakosra jutó aránya, éppúgy, mint a teljes termékenységi arányszám a 19. század vége óta a demográfiai átmenet folyamataihoz illeszkedve csökkent. És bár a háború ideje alatt a születésszám drasztikusan zuhant, 1919-től kezdve visszaállt arra a pályára, amelyen a világégés előtti évtizedekben haladt (2. ábra).

A halálozás trendjében a háború éveiben kismértékủ csökkenés mutatkozott, ami a születések számának jelentős visszaesésével magyarázható. A magas csecsemőhalandóság mellett az újszülöttek számának csökkenése az ezer före vetített halálozások számarányában csökkenést hozott ugyanis magával. Kiugró halálozás jellemzi viszont a háborút követő spanyolnátha időszakát. Azonban már középtávon tekintve a folyamatot, az látható, hogy a halálozások számarányának lassú csökkenésében csak kitérőt jelentettek ezeknek az éveknek a kilengései (3. ábra). A halálozási adatok javulása, amely nagy részben a csecsemő- és gyermekhalandóság fokozatos visszaszorulásának volt köszönhető, olyan folyamat volt, amelyet tartósan a háború és következményei sem tudtak megakasztani.

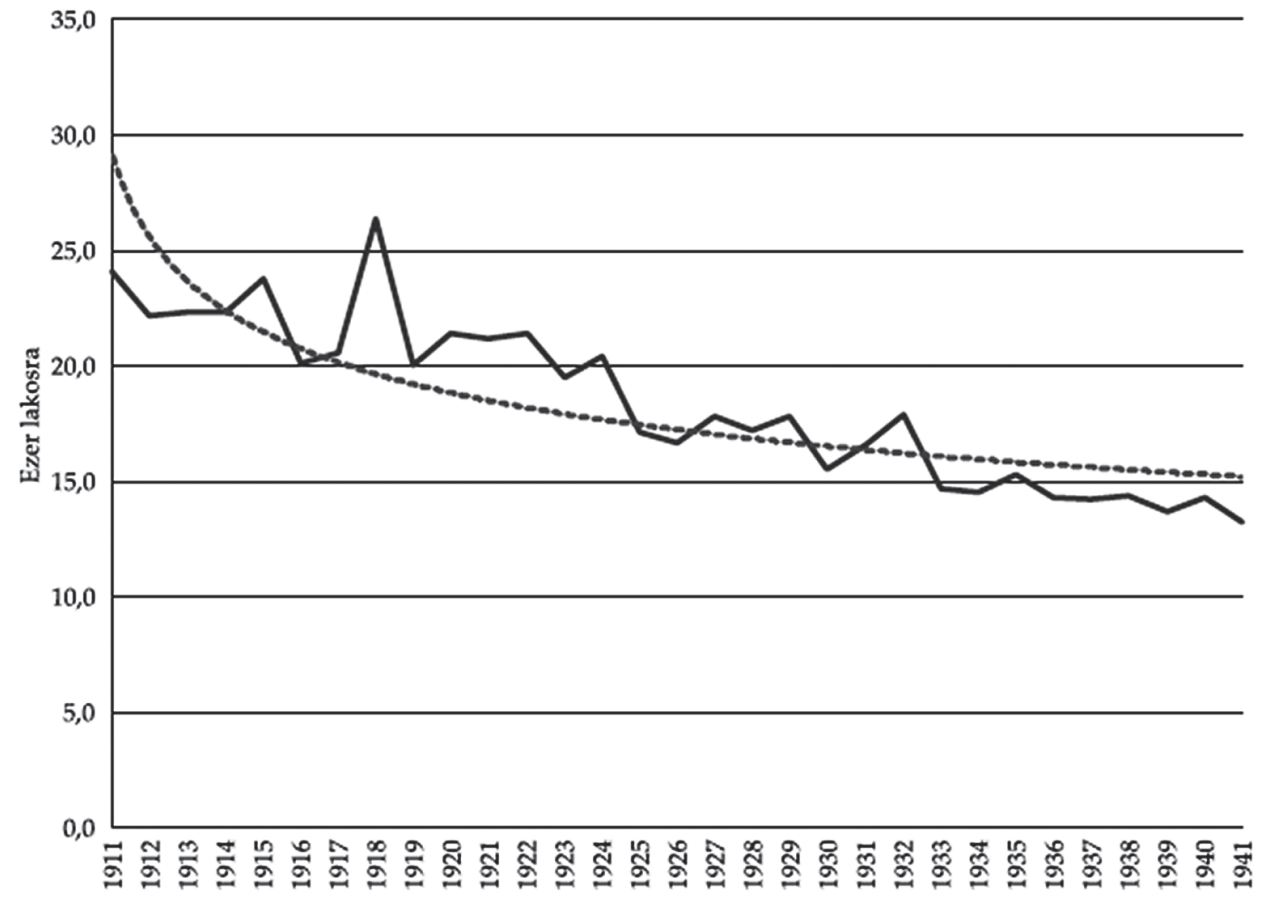

3. ábra. A halálozások ezer lakosra eső arányának változása a trianoni Magyarország területén, 1911-1941 (Koloh, 2018, 31.) 
A halandóság kedvező alakulását más oldalról természetszerüleg a várható élettartam növekedése kísérte. Ez a számítások szerint még 1910 és 1920 között is növekedett valamelyest, hogy azután az 1920-as évek második felétől újra gyors ütemben javuljon (Tomka, 2011, 201.).

Az első világháború, majd az összeomlás, bár rövid távon jelentősen befolyásolta az egyes emberek viselkedését, ami az olyan döntéseket illeti, mint házasságkötés vagy gyermekvállalás, ám a Magyarországon megfigyelhetö hosszabb távú demográfiai trendekben nem okozott törést.

Nyilvánvalóan óriásiak és tartósak voltak azonban a háború és az Osztrák-Magyar Monarchia, benne Magyarország felbomlásának gazdasági kihatásai. Első pillantásra a negatív következmények ötlenek szembe; a humántőke vesztesége, az infláció, amit a kormányok háborús hitelfelvételei indítottak el, és az addigi gazdasági kapcsolatok általános szétesése egész Közép-Európában. Ugyanakkor a háború számos olyan technikai vagy intézményi változást hozott, Magyarországon újnak számító fejlődési irányt indított be, amelyek a következő évtizedekben bontakoztak ki igazán. A háborús konjunktúra nyomán a trianoni Magyarország területén az ipari kapacitások a géppark lóerőben kifejezett teljesítményén mérve nagyobbak voltak 1921-ben, mint 1913-ban ugyanazon a területen (Tomka, 2018, 71.). Szintén a háborús nehézségek innovációt előmozdító hatásai közé tartozik, hogy ekkor tervezték el először a vasutak villamosítását, amit a szénhiány közepette elérni remélt energiamegtakarítás indokolt. Persze ennek első lépései is csak a háború után történtek meg, teljeskörúen pedig csak a 20. század második felében álltak le a gőzmozdonyok (Nagy P., 2018). Egy másfajta háborús innováció a jövedelemadó bevezetése volt - amelyet ugyan már korábban terveztek -, s bár ez a háború finanszírozásában nem tett ki nagy tételt, a továbbiakban is a rendszer része maradt (Pogány, 2018).

Persze az ilyen, hosszabb távon érzékelhető hatásokkal rövid távon a gazdasági erőforrások háborús kimerülése, illetve egy tetemes hányadának elvesztése állt szemben. A vasérctermelés $89 \%$-a, az erdők $84 \%$-a, egyes bányászati ágazatoknak szinte teljessége (feketeszén, só, réz) került az ország határain kívülre, a közlekedési infrastruktúra szétdarabolódott, stb. Ugyanakkor az elektronikai ipar vagy a gépipar túlnyomó hányada magyar területen maradt, $\mathrm{s}$ ezek termelékenyebb, magasabb hozzáadott értéket elóállító ágazatok voltak, ami a későbbi gazdasági fejlődés szempontjából kedvező volt.

A háború következtében katasztrofális helyzetbe kerültek az állam pénzügyei is, és komoly társadalmi és politikai konfliktusok kapcsolódtak a centralizált hadigazdaságot irányító intézmények működéséhez, illetve ezek felszámolásához a háború után. 1914-től kezdve a modern háború kiszolgálása érdekében a munkaerővel, nyersanyagokkal, élelmiszerekkel és iparcikkekkel mindinkább központosított módon gazdálkodtak. Az addig túlnyomóan piaci koordinációt a gazdaságban mindinkább az állam általi, kormányzati szervek végezte elosztás 
vette át. Ezzel az addigi gazdasági jellegü konfliktusok politikai konfliktusokká váltak, hiszen az érdekeltek úgy érezhették, hogy önvédelmük lehetősége a kormányra, hatóságokra gyakorolt politikai nyomásgyakorlásban rejlik. Ennek mozgósító hatása is volt, vidéken és városban egyaránt tömegek kezdtek érdeklődni a politika kérdései iránt, mi több, szervezetekbe is tömörülni. Ilyen konfliktusok alakultak ki például a szén elosztása körül, amelyből az ország amúgy a békeidőkben is behozatalra szorult. A háború során korlátozni kellett a lakossági energiafelhasználást - a szénből előállított városi gáz használatát is a gázégőkben - s megoldani a szénkészletek elosztását az ipar, a közlekedés és a mezőgazdaság között, utóbbinak a cséplőgépek üzemeltetéséhez volt szüksége nagy mennyiségű szénre. A háború végére külön kormánybiztosság végezte a szén beszerzését és elosztását, amely azután még évekig fennmaradt, míg a szabadpiaci viszonyok újra helyre nem álltak. A szénhiány folytán előálló gazdasági és társadalmi katasztrófa elkerülése érdekében 1919-től a győztes nagyhatalmak révén Magyarország szénszállítmányokat is kapott Sziléziából és Csehországból (Nagy P., 2018).

Még élesebb politikai konfliktusok keletkeztek az élelmiszer-ellátás, különösen a kenyérgabona-félékkel való centralizált gazdálkodás nyomán. A Haditermény Rt. müködésével - amelyben a nagy gabonakereskedelmi cégek, gőzmalmok, a föváros vett részt, és tulajdonképpen a kormányzati élelmezéspolitika végrehajtója volt - vidéken éppúgy elégedetlenek voltak, mint városban, $s$ mind a termelők, mind az élelmiszerfogyasztók meg voltak róla győződve, hogy a kormány a másik oldal érdekeit védi velük szemben. Az 1918 novemberében a falvakban országszerte kitört zavargások mögött nem kizárólag, de jelentős mértékben a termés ismételt lefoglalása és jelentős részének szabott áron való beszolgáltatása miatt felgyülő feszültség volt a kiváltó ok. A falvak „forradalma” az összeomlás pillanatában más logikát mutatott, mint a városoké, ahol a tömegek politikai cselekvését a politikai szereplők egy kormány-, illetve rendszerváltoztatás, s ezzel együtt a politikai elit összetételének változása irányába tudták kanalizálni. Falun ezzel szemben az egalitárius törekvések, a nagyobb birtokok megtámadása, a közigazgatással és a gazdagokkal szembeni lázadás, az élelmiszerraktárak széthordása, az iparcikkeket ,jogos zsákmánynak” tekintő morális ökonómia érvényesülése, kiegészülve a frontokról hazatérők dühével nem illeszkedett a városi politikai folyamatok világához (Csíki, 2018; Hatos, 2018).

A háború alatt kifejlődött közellátási intézményrendszer és intézkedéstípusok azonban még évekig fennmaradtak. Az intézmény és irányítóinak személyi folytonossága meglepő módon jelentős mértékben keresztülhúzódik az 1918-as és 1919-es év minden politikai változásán. A rendszernek a legnagyobb kihívásokkal talán 1919 nyarán, őszén kellett megbirkóznia. Ekkor a jelentős részben megszállás alá kerülő országban a nem mezőgazdasági termelő népesség élelmiszer-ellátása annyira problematikusnak tűnt, hogy a győztes nagyhatalmakat 
is aggasztotta. A közép-európai rendezés előfeltételének tűnt a népesség élelmezési helyzetének stabilizálása. A Tanácsköztársaság bukása után a gabonaés lisztraktárak brit védelem alá kerültek, hogy a román csapatok ne rabolják ki őket, s 1919-1920 telén az ország valamennyi gabonát is kapott külföldröl (Bódy, 2018a).

A következő időszakban az élelmezéspolitika a társadalmi és politikai küzdelmek egyik ütközőpontja maradt. A termelők a mezőgazdasági termékek forgalmának felszabadítását és szabadpiaci árakat követeltek, míg a fogyasztók a hatósági élelmiszerelosztás és a szabott árak fenntartásáért küzdöttek. A gyáripar képviselői, mindenekelőtt a GYOSZ (Gyáriparosok Országos Szövetsége) szintén a kötött élelmiszer-gazdálkodás mellett álltak ki, attól tartva, hogy szabadpiaci forgalom mellett az élelmiszerárak elszabadulását kénytelenek lennének követni béremelések révén, s ez emelné termelési költségeiket. A kormány 1921 nyaráig ragaszkodott a szomszédos országokhoz képest rendkívül alacsony hatósági liszt- és kenyérárak fenntartásához, ami nyilvánvalóan elengedhetetlen volt az új rezsim stabilitásának megteremtéséhez, ami ugyanakkor motiválta a gabonaés liszt külföldre csempészését (Nagy A., 2019; Bencsik, 2020). A kormány az 1921-es aratás értékesítését viszont már a mezőgazdasági termelők érdekében szabaddá kívánta tenni, amiből azonban a kibontakozó hatások miatt részben visszakozni kényszerült. Az állami alkalmazottak és az ipari munkások számára továbbra is fenntartotta lisztből a hatósági fejadagok juttatását. Ezzel a megoldással és azzal, hogy az ipari konjunktúrát és beruházásokat 1921 nyarától egy - nem feltétlenül tudatosan átgondolt - inflációs politika finanszírozta (ami a költségvetés helyzetéből önmagában is következett) sikerült biztosítani, hogy a kormányzat megörizte az egyensúlyt az élelmiszer-termelők és a fogyasztók, illetve az ipar és a mezőgazdaság érdekei között. Az árát ennek elsősorban a malmok fizették meg, mert a kormány az ő szigorú ellenőrzésük és adóztatásuk révén tett szert a hatósági fejadagokhoz szükséges kenyérlisztre. A malomipar azonban nem reprezentált számszerüleg nagy súlyú politikai csoportot, így nem tudott érdemi nyomást gyakorolni a kormányra. Egészen 1924-ig eltartott, amíg a kormány teljesen leépítette a hatósági lisztellátást, és teljeskörüen visszatért a szabadpiachoz az élelmiszer-ellátásban.

Az állam élelmiszer-ellátásból való kivonulásának lassú, folyamatos kivitelezése, a mezőgazdaság jövedelemhez juttatása és közben az ipari konjunktúra inflációs finanszírozása a konszolidáció folyamatában a társadalmi egyensúly kialakításának kulcseleme volt. A folyamat végén vidék és város gazdasági szempontból ismét piaci alapon kapcsolódott egymáshoz, ami békésebb viszonyokat eredményezett, mint amikor a politika próbálta menedzselni e kapcsolatokat (Bódy, 2018a). Vidéken ehhez járult a stabilizáció szempontjából rendkívül fontos házhelyosztás - ami megelőzte a hosszan húzódó földreformot -, illetve maga a közismert Nagyatádi-féle földreform. Utóbbi valójában nem a 
névadó miniszter eredeti koncepciójának felelt meg, arra azonban tökéletesen alkalmas volt, hogy a falusi társadalomban csökkentse a legszegényebbek helyzetének bizonytalanságát, s ezzel hozzájáruljon az új rendszer tartós stabilitásának megteremtéséhez, a vidéki társadalom tekintélyrendjének helyreállításához, úgy, hogy mindeközben csak minimális áldozatot igényelt a nagyobb birtokosoktól (Bódy, 2018b; Nagy J., 2003).

Az infláció, hasonlóan más európai államokhoz, nemcsak a háború utáni rekonstrukció - nem feltétlenül tudatosan alkalmazott - eszközévé vált, hanem következett az állam háborús eladósodásából is. A háború végén Magyarország összes adóssága az 1913-as GDP 385\%-ára rúgott (Pogány, 2018, 87.). A költségvetés bevételei hosszú ideig egyáltalában nem álltak arányban a kiadásokkal, s ráadásul Magyarországot jóvátételi kötelezettség is terhelte, amelynek összege ugyan a békeszerződés után is bizonytalan maradt, viszont fedezetéül a magyar állam összes bevételére zálogjog illette meg a győztesek képviselőiből álló Jóvátételi Bizottságot. Ez évekig olyan bizonytalansági tényezőt jelentett, amely lehetetlenné tette, hogy Magyarország a nemzetközi pénzpiacon felvett kölcsönnel stabilizálja költségvetését, illetve finanszírozzon beruházásokat. Ezért a kormányok eleinte adóemelésekkel - a jövedelemadó progreszszív megemelésével, a földadó megtízszerezésével - próbálkoztak, továbbá a forgalomban lévő pénzmennyiség egy részének kivonásával, majd egy egyszeri nagy és szintén progresszív adókulccsal dolgozó vagyonváltság révén próbálták az inflációt megállítani, és a költségvetést az egyensúlyi helyzethez közelíteni. Ezek az akciók azonban egyrészt társadalmi ellenállást váltottak ki, és a pénzügyminisztereknek nem sikerült megfelelö tartós politikai támogatást biztosítaniuk mögéjük, illetve a részleges siker időszakában az elindult deflációs folyamat lefékezte a gazdaságot. Ezért a kormány 1921 közepétől inkább külső kölcsön révén remélte a stabilizációt végrehajtani, ami végül 1924-ben vált valóra. Ekkor tértek csak vissza a háború kitörése után először a rendes törvényhozási úton elfogadott költségvetések és zárszámadások rendjéhez, addig a kormányok mindig rövid időkre szóló felhatalmazási törvényekkel rendezték a költségvetési kérdéseket (Pogány, 2018).

A költségvetés helyzetének ilyen alakulása aláásta a középrétegek államhoz kötődő foglalkozási csoportjainak helyzetét, hiszen a kormányok rendre próbálkoztak takarékossági intézkedésekkel, a közszféra fizetéseinek lehető visszafogásával és a létszámleépítésekkel, B-listázásokkal. Az elbocsátott köztisztviselők pedig viszonylag alacsony összegü nyugdíjra számíthattak csupán. Az inflációs években ezért folytatódott a köztisztiviselők reálkeresetének csökkenése, ami már a háború idején is jellemző volt, illetve a közszolgálati álláskínálat szűkülése. Ehhez járult még a menekültek beáramlása, akiknek tapasztalatai - melyek a szélesebb társadalomban a rokonok, ismerősök révén sok, eleve a trianoni területen élő ember számára is hozzáférhetővé válhattak - szintén 
a középosztály lesüllyedéseként értelmeződtek. E folyamatokból állt össze a fix fizetéses középosztály megrendülésének tapasztalata, ami a korábbi ország szétesésének traumájával is szimbolikusan összekapcsolódott. Ebben gyökerezett a középosztály elszegényedéséről szóló rendkívül kiterjedt korabeli diskurzus. Ez képezte vélhetően a legfontosabb mozgatóerőt azon törekvések mögött, amelyek a középosztály vagy a „keresztény társadalom” védelmének jelszava alatt igyekeztek szerveződni. Ezeknek az antiszemita mozgalmaknak voltak következményei - egyebek mellett a numerus clausus törvény -, de a „zsidó sajtótól” elkülönülö, „őrségváltó” keresztény sajtó megteremtése például nem sikerült (Klestenitz, 2018).

Nemcsak a középosztályt, de a városi lakosság egészét is sújtották a lakhatási gondok új jelenségei. A háború éveiben megszűnt a szabad bérlakáspiac, először hatósági lakásnyilvántartás és közvetítés jött létre, majd pedig a háború végén megszületett a hatósági lakáskiutalás rendszere (miközben elvileg a lakások magántulajdonban maradtak). A lakáshivatallal együtt olyan fogalmak születtek meg, mint a jogos lakásigény, lakáskiutalás, sőt egy átmeneti időre a lakásrekvirálás. A lakásrendeletek előkészítése és kiadása az érdekeltek állandó konfliktusai és politikai összeütközései közepette történt. Bár a háború előtt is létezett a lakáskérdéssel kapcsolatban szociálpolitikai diskurzus, ez elsősorban a legszegényebbek egészségtelen, túlzsúfolt lakhatási viszonyaival foglalkozott. A háború nyomán azonban az a kérdés, hogy kinek mi a jogos lakásigénye úgyszólván az egész társadalmat érintette már (Nagy Á., 2018). A lakhatási válságot súlyosbította a menekültek érkezése, akiknek integrációjában kulcslépés volt a lakhatásuk biztosítása (Szűts, 2017). A lakhatási válság megoldását nehezítette, hogy a rögzített lakbérek mellett a háború után sem indult meg a piaci alapú lakásépítés. Ezen a kormányzat különböző építési akciókkal - köztisztviselők számára támogatott házépítési hitelekkel - igyekezett segíteni, illetve vidéken a nagy volumenű falusi kislakás-építési akcióval. Érdemi változást csak a lakbér rögzítésének feloldása és a társadalombiztosítási nyugdíjalapok egy részének ingatlanba fektetése hozott. Mindez azonban inkább csak az 1920-as évek második felében jelentkezett (Bódy, 2004).

A háború által kiváltott vagy felgyorsított társadalmi változások közül az egyik legfontosabb a nők helyzetének változása volt. 1910 és 1920 között a statisztika kimutatása szerint hozzávetőleg 7\%-kal nőtt a nők aránya a keresők között, s ezzel 30\%-on állt. Ez azonban csalóka adat, mert a parasztlányok és asszonyok jelentős tömege bár nem keresőként szerepelt a népszámlálásokban, de természetesen mindig is keményen dolgozott. A növekedés legnagyobb arányú a közlekedésben volt, és a közszolgálatban - itt 31,5\%-ra ment föl a női munkavállalók aránya -, de még az östermelésben is jelentős növekedés volt megfigyelhetö, bizonyára az elesett férfiak helyét a statisztikában is átvevő nők révén (Sárai Szabó, 2018, 262-263.). A háború a falusi társadalomban is elindította a „nőemancipá- 
ció" egyfajta hullámát. A bevonult férfiak helyett sok nőnek kellett ellátni olyan feladatokat, amelyek korábban szigorúan a férfiak kompetenciájába tartoztak a falusi társadalomban, s ez nem múlt el nyom nélkül a háború után sem (Jávor, 2000). Általában is, a háború fellazította a faluközösségek zárt rendjét, hiszen sokan kerültek tartósan távol addigi lakhelyükről, és sok faluban jelentek meg idegenek, katonák vagy még gyakrabban a gazdaságokba munkaerőként kiutalt hadifoglyok.

A növekvő női munkavállalás új típusú problémákat hozott felszínre. Az első világháború előtt a feminista mozgalom közvetlen politikai céljai álltak az előtérben, mint például a női választójog. Az 1920-as években a női választójog - ha nem is a férfiakéval azonos szinten - formálisan adott volt. Az új foglalkozások nők elötti megnyílásával megjelentek viszont olyan problémák, mint például a lányok pályaválasztásának kérdése. A középrétegekbe tartozó nők mind gyakoribb kereső tevékenysége nyomán pedig széles körben kezdték vitatni, hogy miként egyeztethető össze a női munkavállalás és a család, a gyermekvállalás. A női kereső munkatevékenységben a középosztályban sokan a család intézményének hanyatlását látták, mert a korábbi normák szerinti házasságot, amelyben a nő a férje eltartottja, az egyetlen lehetséges családmodellként fogták fel. Mások viszont a nők keresőtevékenységében és a kétkeresős családmodell megjelenésében az egyenlőségen - és az anyagi szempontok helyett érzelmeken - alapuló házasság kialakulásának lehetőségét látták (Sárai Szabó, 2018; Papp-Sipos, 2017).

Minden nehézségen túl, a magyar gazdasági szereplők a kormányzati gazdaságpolitika által támogatva összességében meglepően sikeresen alkalmazkodtak ahhoz, ahogyan a háború hatásai és az új államok születése átrendezte a gazdaság térszerkezetét. A háborús konjunktúra végével sok, addig gazdasági szempontból belföldinek minősülő tőkekapcsolat, piaci kapcsolat külkapcsolattá válása mellett - hiszen az Osztrák-Magyar Monarchia szétesett - kellett elvégezni a gazdasági rekonstrukció feladatait, és alkalmazkodni az új nemzetközi gazdasági környezethez. A megmaradt ipar haditermelésről való átállása más profilokra komoly tőkebefektetést igényelt, csakúgy, mint a piacvesztések miatt talajt vesztett gazdasági tevékenységek helyett újabbak beindítása. Ezt az 1920-as évek első felében - egy közgazdaságilag konzervatív szemléletủ stabilizációs kísérlet bukása után - alapvetően inflációs pénzteremtéssel finanszírozták, az évtized második felében pedig jelentős, részben külföldröl történő tőkebevonással, ami a Magyar Nemzeti Bank 1924-es megalapítása, és az ún. népszövetségi kölcsön fölvétele után indult be nagyobb arányban. Összességében ez a folyamat elég gyorsan és figyelemre méltó eredménnyel ment végbe. 1925-re a gazdasági kibocsátás szintje meghaladta a trianoni területre vetítve az utolsó békeév szintjét. 1929-re az egy före jutó bruttó hazai termék 18\%-kal haladta meg az 1913. évit (Tomka, 2018). Figyelembe véve a háború gazdasági 
veszteségeit és a korábban egységes gazdasági teret alkotó Osztrák-Magyar Monarchia szétesését, ez igen figyelemreméltó teljesítmény, ami mögött több tényező húzódott meg. Egyrészt a változások következtében leépülő iparágak - például malomipar - helyett a kormányzati politika segítette egyes iparágak fejlődését, amennyiben vámvédelemmel erősítette hazai versenyképességüket (aminek árát jelentős részben a mezőgazdaság fizette meg). Ez hozzájárult ahhoz az amúgy is zajló átstrukturálódási folyamathoz, amelyben a mezőgazdaság aránya a nemzeti jövedelem megtermelésében fokozatosan csökkent az iparral és a szolgáltatással szemben. Ez azt jelentette, hogy a magasabb termelékenységủ szektorok súlya nőtt a magyar gazdaságban, hiszen ezek tőke- és technológiaigényesebb, magasabb hozzáadott értéket elóállító ágazatok, mint a mezőgazdaság. Egyes magyar vagy Magyarországon működő, de külföldi anyacéghez kapcsolódó iparvállalatok világszínvonalon is élenjárónak számító konstrukciójú termékekkel rendelkeztek (Tungsram - Egyesült Izzó, Ganz Villamossági Rt., Magyar Siemens Müvek, Standard Villamossági Rt. stb.). A hoszszabb távú gazdasági növekedés megalapozása szempontjából lényeges volt a humántőke színvonalának emelése is. Az elemi iskoláztatás általánossá válása a dualista korszak utolsó időszakára és az ennél magasabb szintủ képzések kiszélesedése jó alapot teremtett a későbbi gazdasági növekedéshez a humántőke gyarapodásának szempontjából, s az 1920-as évek oktatáspolitikája az elemik szintjére vonatkozó iskolaépítési programjával és a középfokú képzések bővítésével ezt csak folytatta (Tomka, 2018). Mindezen tényezőknek köszönhetően a Trianonnal bekövetkező változásokhoz a magyar gazdaság sikeresen alkalmazkodott. Ez nemcsak a háború előtti szinttel való már említett összehasonlításban látszik, hanem a nyugat-európai országokhoz mért relatív magyar pozíció alakulásán is. Az egy főre jutó hazai össztermék alakulását összehasonlítva az látható, hogy az első világháború előtti időszakban Magyarország tartani tudta, vagy kismértékben javította relatív pozícióját. Az összeomlást követő dezorganizációban azután ez 1920-ra jelentősen romlott, ám az 1920-as évek végén már közelében járt annak a szintnek, ahol a világháború elött is volt (1. táblázat).

A magyar gazdaság növekedési ütemét tehát a háború és Trianon nem törte meg. Ám miközben ez nemzetgazdasági szinten kétségtelenül igaz, nem jelenti azonban azt, hogy a megmaradó Magyarország - és az elcsatolt területek - egyes régióinak, településeinek ne jelentett volna olyan törést az új határok meghúzása, ami megszakította korábbi fejlődésüket. Számos példa mutatja - az új határokon belül és kívül egyaránt -, hogy egyes városok vagy régiók fejlődését az ország felosztása hosszabb távon is megakasztotta. Ez a korábban az adriai kereskedelemben érdekelt Kaposvárról éppúgy elmondható, mint Nagyváradról vagy számos más határ menti városról és térségről is (Kaposi, 2008; Fleisz, 2005; Gaucsík, 2016). Az érintett települések fejlődési pályáját Trianon így minden bizonnyal mind a mai napig meghatározza. 
1. táblázat. Az egy före jutó bruttó hazai termék alakulása

Magyarországon és Nyugat-Európában, 1890-1950 (1990-es Geary-Khamis nemzetközi dollár)

\begin{tabular}{|l|c|c|c|c|c|c|c|c|c|c|}
\hline & $\mathbf{1 8 9 0}$ & $\mathbf{1 9 0 0}$ & $\mathbf{1 9 1 0}$ & $\mathbf{1 9 1 3}$ & $\mathbf{1 9 2 0}$ & $\mathbf{1 9 2 9}$ & $\mathbf{1 9 3 0}$ & $\mathbf{1 9 3 8}$ & $\mathbf{1 9 3 9}$ & $\mathbf{1 9 5 0}$ \\
\hline $\begin{array}{l}\text { Magyar- } \\
\text { ország }\end{array}$ & 1473 & 1682 & 2000 & 2098 & 1709 & 2476 & 2404 & 2655 & 2838 & 2480 \\
\hline $\begin{array}{l}\text { Nyugat- } \\
\text { Európa átlaga }\end{array}$ & 2535 & 2910 & 3269 & 3474 & 3247 & 4336 & 4301 & 4667 & 4867 & 5467 \\
\hline $\begin{array}{l}\text { Mo./Ny.-Eu. } \\
\text { átlag } \times 100\end{array}$ & 58,1 & 57,8 & 61,2 & 60,4 & 52,6 & 57,1 & 55,9 & 56,9 & 58,3 & 45,4 \\
\hline
\end{tabular}

Megjegyzések: Nyugat-Európa: Egyesült Királyság, Franciaország, Hollandia, Belgium, Írország, Németország, Ausztria, Svájc, Svédország, Dánia, Norvégia, Finnország, Olaszország. Írország esetében 1910-nél is az 1913-as adat szerepel, 1920 helyett pedig 1921. Magyarország 1890-1950: a trianoni határokon belül (Tomka, 2018, 77.)

\section{IRODALOM}

Bencsik P. (2020): The New Borders as Local Economic Possibility? The Case of Post-1920 Hungary. Kézirat

Bódy Zs. (2004): Kislakás, társasház, családi ház. Lakásépítkezés és az otthon ideáljának változása Budapesten az első világháború körül. Századvég, 4, 27-57. https://www.yumpu.com/hu/ document/read/16462476/body-zsombor-kislakas-tarsashaz-csaladi-haz-lakasepitkezes-es-/3

Bódy Zs. (2018a): Élelmiszer-ellátás piac és kötött gazdálkodás között a háború és az összeomlás idején. In: Bódy Zs. (szerk.): Háborúból békébe: A magyar társadalom 1918 után. Budapest: MTA BTK TTI, 151-194.

Bódy Zs. (2018b): Gyár és földbirtok a nagy háborúban és az összeomlásban. Századok, 152, 6, 1261-1292. https://www.academia.edu/40428128/Gy\%C3\%A1r_\%C3\%A9s_f\%C3\%B6ldbirtok_a_nagy_h\%C3\%A1bor\%C3\%BAban_\%C3\%A9s_az_\%C3\%B6sszeoml\%C3\%A1sban

Csíki T. (2018): A parasztság „forradalma” 1918-ban. In: Bódy Zs. (szerk.): Háborúból békébe: A magyar társadalom 1918 után. Budapest: MTA BTK TTI, 129-149.

Fleisz J. (2005): Egy város átalakulása. Nagyvárad a két világháború között. Nagyvárad: Literátor Könyvkiadó

Gaucsík I. (2016): Válság és reintegráció. A Rimamurányi-Salgótarjáni Vasmű helyzete az első világháború után (1918-1924). In: Kövér Gy. - Pogány Á. - Weisz B. (szerk.): Magyar Gazdaságtörténeti Évkönyv I. Budapest: MTA BTK-Hajnal István Alapítvány, 217-233.

Hatos P. (2018): Elátkozott köztársaság. Az 1918-as forradalom és köztársaság története. Budapest: Jaffa Kiadó

Jávor K. (2000): A magyar paraszti erkölcs és magatartás. In: Paládi-Kovács A. (főszerk.): Magyar Néprajz. VIII. Társadalom. Budapest: Akadémiai Kiadó, 601-692.

Kaposi Z. (2008): Nagykanizsa gazdasági változásai a trianoni béke következtében. In: Honvári J. (szerk.): 20. századi magyar gazdaság és társadalom. Győr: Széchenyi István Egyetem, 10-24. https://uni.sze.hu/hu_HU/downloadmanager/download/id/244/ 
Klestenitz T. (2018): Sajtó és újságírás Trianon árnyékában. In: Bódy Zs. (szerk.): Háborúból békébe: A magyar társadalom 1918 után. Budapest: MTA BTK TTI, 301-336.

Koloh G. (2018): Magyarország demográfiája és az első világháború. In: Bódy Zs. (szerk.): Háborúból békébe: A magyar társadalom 1918 után. Budapest: MTA BTK TTI, 9-46.

Magyar Statisztikai évkönyv. Új folyam. XXVII. XXVIII. XXIX. XXX. köt. 1919, 1920, 1921, 1922. Budapest, 1925. https://mandadb.hu/common/file-servlet/document/922933/default/doc url/I1C1_19121922_20_oldalcs.pdf

Nagy A. (2019): A hátország rejtőzködő gazdasági stratégiái az első világháborúban. Csempészet az osztrák határ mentén. Múltunk, 4.

Nagy Á. (2018): Korlátozott lakásfogyasztás: lakhatási intézmények és képzetek a háború árnyékában. In: Bódy Zs. (szerk.): Háborúból békébe: A magyar társadalom 1918 után. Budapest: MTA BTK TTI, 221-259.

Nagy J. (2003): Földbirtokpolitika Magyarországon a két világháború között. Budapest: Eszterházy Kiadó

Nagy P. (2018): Harc a szénhiány ellen. A szénkormánybiztosság müködése Magyarországon 1924-1927. In: Bódy Zs. (szerk.): Háborúból békébe: A magyar társadalom 1918 után. Budapest: MTA BTK TTI, 195-220.

Papp B. - Sipos B. (2017): Modern, diplomás nö a Horthy korban. Budapest: Napvilág Kiadó

Pogány Á. (2018): Az állami pénzpolitika Magyarországon, 1918-1924. In: Bódy Zs. (szerk.): Háborúból békébe: A magyar társadalom 1918 után. Budapest: MTA BTK TTI, 81-127.

Révész T. (2019): Nem akartak katonát látni? A magyar állam és hadserege 1918-1919-ben. Budapest: MTA BTK TTI

Sárai Szabó K. (2018): A munkavállaló nő az első világháború után. In: Bódy Zs. (szerk.): Háborúból békébe: A magyar társadalom 1918 után. Budapest: MTA BTK TTI, 261-300.

Szűts I. G. (2017): Elűzöttek. Menekültek, optánsok, vagonlakók. Rubicon, 7-8, 52-61.

Tomka B. (2011): Gazdasági növekedés, fogyasztás és életminőség. Budapest: Akadémiai Kiadó

Tomka B. (2018): Az első világháború és a trianoni béke gazdasági hatásai Magyarországon. In: Bódy Zs. (szerk.): Háborúból békébe: A magyar társadalom 1918 után. Budapest: MTA BTK TTI, 47-79. 